\title{
Population Dynamics and Biological Patterns of Commercial Crustacean Species in the Antalya Bay, Eastern Mediterranean Sea: III. The Giant Red Shrimp Aristaeomorpha foliacea Risso,
} 1827

\author{
Mehmet Cengiz Deval ${ }^{1, *}$ (i)
}

${ }^{1}$ Akdeniz University, Faculty of Fisheries, Dumlupınar Bulvarı 07058 Kampüs, Antalya, Turkey.

\begin{abstract}
Article History
Received 29 May 2019

Accepted 25 June 2019

First Online 1 July 2019
\end{abstract}

\section{Corresponding Author}

Tel.: +902422262012

E-mail: deval@akdeniz.edu.tr

\section{Keywords}

Red shrimp

Aristaeomorpha foliacea

Population dynamics

Growth

Reproduction

\begin{abstract}
Current study focuses on the population dynamic and pattern of the giant red shrimp A. foliacea as the third part of series on commercial crustaceans in the study area. Uniand multi variate analysis on the spatio-temporal distributions of the density, biomass, reproduction pattern, age and growth parameters, mortality and the exploitation status of the stock of the species distributed in the area were evaluated. The highest average value of BI $\left(79.9 \mathrm{~kg} \mathrm{~km}^{-2}\right)$ and $D_{\text {TOT }}\left(5105 \mathrm{n} \mathrm{km}^{-2}\right)$, were estimated from the 500 $\mathrm{m}$ stratum. Mature individuals distributed in deeper than $400 \mathrm{~m}$, and the recruits were available between 400-699 $\mathrm{m}$ depth. The gonadosomatic index of $A$. foliacea females showed a sharp increase between May and August, and the first maturation size (FMS) was estimated $\approx 39 \mathrm{~mm}$ (1.8 age). Examining the general pattern of the frequency distributions revealed maximum 3-year modes for males while females displayed 5year modes. Since current level of fishing mortality $\left(F_{\text {cur }}=0.848\right.$ year $\left.{ }^{-1}\right)$ is higher than reference point $\left(F_{0.1}=0.540\right.$ year $\left.^{-1}\right)$ and too close to $F_{\max }\left(=0.960\right.$ year $\left.{ }^{-1}\right)$, the stock of $A$. foliacea females had a potential for the growth overfishing.
\end{abstract}

\section{Introduction}

Aristaeomorpha foliacea is a deep-water benthopelagic shrimp with a reported depth distribution range of $120-1300 \mathrm{~m}$, population density of the species varies between 500 and $700 \mathrm{~m}$ (Politou, Kapiris, Maiorano, Capezzuto \& Dokos, 2004). Although the species known to be distributed in the eastern and central Mediterranean basin, it is rarely present in the western Mediterranean (Palmas et al., 2014).

Fishing efforts targeting the red shrimps, $A$. foliacea and Aristeus antennatus, have increased in the last two decades in deep-water areas of the Mediterranean coasts of Turkey (Deval, Bök, Ateş \& Tosunoğlu, 2009). Annual landings of these species reported to be 1382 tons in 2017 (Anonymous, 2018).
According to Turkish Fisheries Regulations, no minimum landing size (MLS) is defined for these crustacean species, accept the annual fishing prohibition period between 15 April and 15 September for bottom trawlers (Anonymous, 2016).

There is quite comprehensive literature available on the $A$. foliacea in the central part of the Mediterranean on distribution, age and growth, (Yahiaoui, 1994; D’Onghia, Maiorano, Matarrese \& Tursi, 1998; Cau et al., 2002; Papacostantinou \& Kapiris, 2003; Politou et al., 2004), reproduction (Mura, Campisi \& Cau, 1992; D’Onghia, Matarrese, Tursi \& Maiorano, 1994; Belcari, Viva, Mori \& De Ranieri, 2003; Ragonese et al., 2004; Kapiris \& Thessalou-Legaki, 2009) and selectivity (Ragonese, Bianchini \& Di Stefano, 2002; Carlucci, D'Onghia, Sion, Maiorano \& Tursi, 2006). In the 
north Levant Sea, limited amount of available studies were focused on the morphometric relationship (Can \& Aktaş, 2005), trophic ecology (Bayhan, Cartes \& Fanelli, 2014) and selectivity (Deval et al., 2009; Deval, Özgen \& Özbilgin, 2016)

The Mediterranean Sea is among the best-known seas of the world (Coll et al., 2010), but available knowledge on the biota of the bathyal grounds of its Levantine basin is limited, as only few deep-sea expeditions focused on the region in the past (Deval \& Froglia, 2016). Recent scientific surveys on the trawling grounds of the continental slope (between 200 and 900 $\mathrm{m}$ ) of the Antalya Bay, yielded very detailed information on the deep-sea commercial crustacean species in the Turkish coast of the Mediterranean Sea. Population dynamics of both the deep-water rose shrimp (Parapenaeus longirostris) and the blue-red shrimp ( $A$. antennatus) have been already reported (Deval \& Kapiris, 2016; Deval, Kaya \& Olguner, 2019, article in progress). Herein, the population dynamic and pattern of the giant red shrimp $A$. foliacea is reported as the third paper of the series on commercial crustaceans in the area.

\section{Material and Methods}

Aristaeomorpha foliacea samples were collected throughout three bottom trawl surveys in the Antalya Bay; i) DEEP; conducted between October 2009 and June 2010 at depths of 400-560 m, ii) STRATUM; covers eight bathymetric strata between 200 and $900 \mathrm{~m}$ and carried out from July 2010 to June 2011, and iii) REPR; carried out in summer 2012, as previously described by Deval \& Kapiris (2016), Deval, Yılmaz \& Kapiris (2017), Deval, Kebapçıŏlu, Güven \& Olguner (2018).

To identify the gonad development stages of $A$. foliacea, total weight (TW $0.1 \mathrm{~g}$ ) and gonad weight (GW, $0.001 \mathrm{~g}$ ) of 40 female individuals with $\mathrm{CL} \geq 38 \mathrm{~mm}$ were evaluated monthly between October 2009 and November 2010 in accordance to the ICES report (2010).

Two different codends in nominal mesh sizes of 44

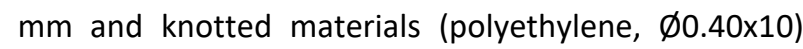
were used for a total of 16 hauls (9 hauls with 44 diamond mesh (44DM) and 7 hauls with 44 square mesh (44SM)).

Uni-and multi variate analysis on the spatiotemporal distributions of the density, biomass, reproduction pattern, age and growth parameters, mortality and the exploitation status of $A$. foliacea were carried out in concordance to the methodologies described by Deval \& Kapiris (2016) and methods of the selectivity, nursery and spawning area mapping as described by Deval et al. (2018).

\section{Results}

During the DEEP and STRATUM surveys (two complete years), a total of 33166 individuals of $A$. foliacea were sampled monthly with hauls carried out 1 to 5 hours (107 trawl operations with a total of $145.2 \mathrm{~h}$ ) (Table 1). Biomass (BI, $\mathrm{kg} \mathrm{km}^{-2}$ ), catch per unit effort (CPUE, $\mathrm{kg} \mathrm{h}^{-1}$ ) and overall density (Dтот, $\mathrm{n} \mathrm{km}^{-2}$ ) indices of $A$. foliacea were collected through the surveys and reported for every stratum in Table 1.

Monthly carapace length $(\mathrm{CL}, \mathrm{mm})$ standardized frequency distributions (SLFD) of both surveys were illustrated separately for each sex in Figure 1 . While the $\mathrm{CL}$ of males ranged from 12 to $52 \mathrm{~mm}$ with a mean of $33.9 \pm 3.5 \mathrm{~mm}$, females ranged from 13 to $65 \mathrm{~mm}$, with a mean of $37.2 \pm 8.6 \mathrm{~mm}$ in the STRATUM survey. A statistical significant difference was detected for the mean carapace length $(\mathrm{t}=2.81, \mathrm{P}<0.05)$ and length frequency distributions between sexes (KolmogorovSmirnov test, $D_{\text {obs. }}=6.852>D_{\text {crt. }}=0.0249 ; P<0.001$ ). For the DEEP survey, the mean $\mathrm{CL}$ of males and females were $34.5 \pm 3.6 \mathrm{~mm}$ and $37.0 \pm 8.6 \mathrm{~mm}$ respectively. The SLFD's from the STRATUM survey illustrated separately for all depth zones in Figure 2. A statistically significant positive length-depth trend observed in both males $(r=0.967, p<0.01)$ and females $(r=0.971, p<0.01)$ (Figure 2).

A. foliacea was present in 53 hauls carried out in deeper than $400 \mathrm{~m}$. Dтот and $\mathrm{BI}$ indices fluctuated between 20 and $\sim 11000 \mathrm{n} \mathrm{km}^{-2}$, and between 0.7 and $206.2 \mathrm{~kg} \mathrm{~km}^{-2}$, respectively. About $88 \%$ of total biomass of $A$. foliacea was found between 500 and $600 \mathrm{~m}$ stratums (Table 1). Highest average value of $\mathrm{BI}(79.9 \mathrm{~kg}$ $\mathrm{km}^{-2}$ ) and Dтот (5105 $\mathrm{n} \mathrm{km}^{-2}$ ) were calculated for the samples collected from the $500 \mathrm{~m}$ stratum (Figure 3 ). Two-way MANOVA analyses revealed a significant effect of only depth on the $\mathrm{D}_{\text {TOT, }} \mathrm{BI}$ and some other fractions $(p<0.01$, Table 2). However, no significant effect of season was detected on indices and fractions $(P>0.05$, ). The overall average value of Dтот and BI were $3979 \mathrm{n} \mathrm{km}^{-}$ ${ }^{2}$ and $69.4 \mathrm{~kg} \mathrm{~km}^{-2}$ for DEEP and $3803 \mathrm{n} \mathrm{km}^{-2}$ and $71.5 \mathrm{~kg}$ $\mathrm{km}^{-2}$ for REEP surveys (Table 1 ).

The correlation analysis between density values $(\log X+1)$ of 116 sampled species from the STRATUM survey with $A$. foliacea indicated a positive correlation only for 12 species (Table 3 ). These results point out that A. foliacea shares its habitat mostly with these species.

The recruitment pattern of $A$. foliacea displayed difference annually for the following two sampling years. In the DEEP survey, first recruits of 2009 cohort (14-19 $\mathrm{mm} \mathrm{CL}$ ) was observed in December (0.6\%) and after two months in February 2010 recruit group much more pronounced (3.4\%). The mean $\mathrm{CL}$ of recruit group of female in February 2010 was $16.0 \pm 1.4 \mathrm{~mm}$. In the fallowing months CL were $22.3 \pm 1.8 \mathrm{~mm}$ in April, $24.3 \pm 2.1 \mathrm{~mm}$ in May and $25.7 \pm 2.3 \mathrm{~mm}$ in July. The first recruit of the 2010 cohort observed relatively late in April 2011 (20.7 $\pm 1.8 \mathrm{~mm} \mathrm{CL})$ in STRATUM survey. To identify the recruit fraction of the population in each haul, cut-off lengths ( $C L \leq 32 \mathrm{~mm}$ for January, $\leq 30 \mathrm{~mm}$ for October and December, $\leq 28 \mathrm{~mm}$ for November and the cut-off length were stable $\leq 26 \mathrm{~mm}$ from February to September) were calculate by the analysis of the mean $\mathrm{CL}$ of the first modal groups. During the STRATUM 


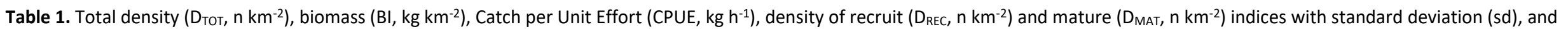
$D_{\mathrm{REC}} / D_{\mathrm{TOT}}$ and $D_{\mathrm{MAT}} / D_{\mathrm{TOT}}$ fractions by surveys for $A$. foliacea in the Antalya Bay. (DR: Depth range, Hn: Number of hauls, OH: Hauls in occurrence, TT: Trawling time, $\mathrm{n}$ : number of specimens caught, M: male, F: female, SR: sex ratio).

\begin{tabular}{|c|c|c|c|c|c|c|c|c|c|c|c|c|c|c|c|}
\hline \multirow[b]{2}{*}{ Surveys } & \multirow[b]{2}{*}{$\mathrm{DR}(\mathrm{m})$} & \multirow[b]{2}{*}{$\mathrm{Hn}$} & \multirow[b]{2}{*}{$\mathrm{OH}$} & \multirow[b]{2}{*}{ TT } & \multirow[b]{2}{*}{$\mathrm{n}$} & \multicolumn{5}{|c|}{ Indices } & \multicolumn{3}{|c|}{ Fractions } & \multicolumn{2}{|c|}{ Mean CL (mm) } \\
\hline & & & & & & D тот & $\mathrm{BI}$ & CPUE & $D_{\text {REC }}$ & $\mathrm{D}_{\mathrm{MAT}}$ & $\mathrm{D}_{\mathrm{REC}} / \mathrm{D}_{\mathrm{TOT}}$ & $\mathrm{D}_{\text {MAT }} / \mathrm{D}_{\mathrm{TOT}}$ & SR & $M$ & $\mathrm{~F}$ \\
\hline DEEP & $400-560$ & 12 & 100 & 54.9 & 17363 & $3979 \pm 2125$ & $69.4 \pm 40.2$ & $5.33 \pm 3.02$ & $563 \pm 702$ & $2233 \pm 1408$ & 0.154 & 0.529 & 0.496 & $34.5 \pm 3.6$ & $37.1 \pm 8.6$ \\
\hline \multirow[t]{9}{*}{ STRATUM } & 200 & 12 & 0 & 14.6 & - & - & - & - & - & - & - & - & - & - & - \\
\hline & 300 & 12 & 0 & 12.6 & - & - & - & - & - & - & - & - & - & - & - \\
\hline & 400 & 15 & 27 & 29.0 & 1763 & $535 \pm 1017$ & $6.2 \pm 11.7$ & $0.46 \pm 0.9$ & $119 \pm 293$ & $63 \pm 174$ & 0.054 & 0.035 & 0.500 & $29.2 \pm 2.8$ & $35.1 \pm 5.9$ \\
\hline & 500 & 14 & 100 & 23.6 & 6917 & $5105 \pm 4205$ & $79.9 \pm 67.1$ & $5.81 \pm 4.8$ & $678 \pm 871$ & $2583 \pm 2392$ & 0.144 & 0.418 & 0.459 & $30.1 \pm 3.7$ & $35.8 \pm 7.9$ \\
\hline & 600 & 14 & 100 & 24.8 & 6399 & $3912 \pm 2974$ & $72.7 \pm 50.5$ & $5.32 \pm 3.8$ & $416 \pm 881$ & $2519 \pm 1808$ & 0.105 & 0.688 & 0.464 & $31.6 \pm 3.0$ & $40.6 \pm 8.8$ \\
\hline & 700 & 12 & 100 & 12.6 & 583 & $619 \pm 751$ & $13.8 \pm 14.3$ & $1.04 \pm 1.0$ & - & $362 \pm 422$ & - & 0.687 & 0.531 & $32.9 \pm 2.7$ & $45.5 \pm 6.3$ \\
\hline & 800 & 7 & 100 & 7.3 & 136 & $267 \pm 282$ & $8.6 \pm 8.3$ & $0.58 \pm 0.6$ & - & $259 \pm 281$ & - & 0.848 & 0.572 & $34.5 \pm 2.5$ & $48.6 \pm 5.3$ \\
\hline & 900 & 1 & 100 & 1.2 & 5 & 59 & 3.0 & 0.19 & - & 59 & - & 1.000 & - & 34 & $49.5 \pm 6.7$ \\
\hline & Mean & & 83 & & & $2279 \pm 3180$ & $39 \pm 52$ & $2.85 \pm 3.8$ & $272 \pm 642$ & $1248 \pm 1829$ & 0.070 & 0.495 & 0.489 & $33.9 \pm 4.3$ & $37.2 \pm 8.7$ \\
\hline \multirow[t]{2}{*}{ REPR } & $450-650$ & 8 & 100 & 19.3 & 5952 & $3803 \pm 5696$ & $71.5 \pm 98$ & - & - & - & - & - & - & $34.2 \pm 4.3$ & $41.4 \pm 9.3$ \\
\hline & $\Sigma=$ & 107 & & 145.2 & 39118 & & & & & & & & & & \\
\hline
\end{tabular}

Table 2. Results of the two-way MANOVA and non-parametric Spearman's rho correlation analysis for significant testing in all biological indices and fractions (Total density ( $D_{\text {TOT, }} \mathrm{n}$ km ${ }^{-2}$ ), biomass

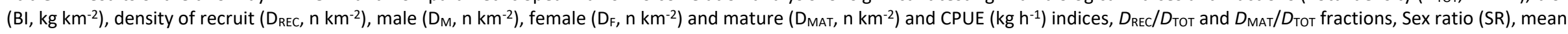
carapace length $(\mathrm{CL}, \mathrm{mm})$ and body weight (TW, g) of $A$. foliacea, between strata and seasons. * are significant at the 0.01 level.

\begin{tabular}{|c|c|c|c|c|c|}
\hline \multirow{2}{*}{$\begin{array}{l}\text { Variables } \\
\text { Independent }\end{array}$} & \multirow[b]{2}{*}{ Dependent } & \multicolumn{2}{|c|}{ Two-Way MANOVA } & \multicolumn{2}{|c|}{ Spearman's rho } \\
\hline & & $F$ & $p$ & $r$ & $p$ \\
\hline \multirow{10}{*}{ Season } & $S R$ & 1.091 & 0.303 & 0.175 & 0.267 \\
\hline & $\mathrm{D}_{\text {Tот }}$ & 0.089 & 0.767 & 0.022 & 0.865 \\
\hline & $\mathrm{BI}$ & 0.022 & 0.883 & -0.029 & 0.819 \\
\hline & CPUE & 0.113 & 0.739 & -0.002 & 0.986 \\
\hline & $\mathrm{D}_{\mathrm{M}}$ & 0.007 & 0.933 & -0.126 & 0.405 \\
\hline & $D_{F}$ & 0.232 & 0.633 & -0.061 & 0.638 \\
\hline & $\mathrm{D}_{\mathrm{REC}}$ & 0.087 & 0.769 & 0.163 & 0.267 \\
\hline & $\mathrm{D}_{\mathrm{MAT}}$ & 0.049 & 0.826 & -0.094 & 0.539 \\
\hline & $\mathrm{D}_{\mathrm{REC}} / \mathrm{D}_{\mathrm{TOT}}$ & 0.335 & 0.566 & 0.184 & 0.210 \\
\hline & $\mathrm{D}_{\mathrm{MAT}} / \mathrm{D}_{\mathrm{TOT}}$ & 2.413 & 0.129 & -0.069 & 0.651 \\
\hline \multirow{12}{*}{ Stratum } & SR & 0.868 & 0.493 & 0.284 & 0.068 \\
\hline & $\mathrm{D}_{\text {тот }}$ & $5.549 *$ & $0.001 *$ & 0.065 & 0.614 \\
\hline & $\mathrm{Bl}$ & $4.820 *$ & $0.003 *$ & 0.134 & 0.294 \\
\hline & CPUE & $4.814^{*}$ & $0.003^{*}$ & 0.127 & 0.320 \\
\hline & $\mathrm{D}_{\mathrm{M}}$ & $4.157^{*}$ & $0.007^{*}$ & $-0.596 *$ & $0.000 *$ \\
\hline & $D_{F}$ & $4.766^{*}$ & $0.004 *$ & -0.106 & 0.409 \\
\hline & $D_{\text {REC }}$ & 1.671 & 0.179 & $-0.618 *$ & $0.000 *$ \\
\hline & $\mathrm{D}_{\mathrm{MAT}}$ & $4.228 *$ & $0.007^{*}$ & -0.243 & 0.083 \\
\hline & $\mathrm{D}_{\mathrm{REC}} / \mathrm{D}_{\mathrm{TOT}}$ & 2.102 & 0.101 & $-0.655^{*}$ & $0.000 *$ \\
\hline & $\mathrm{D}_{\text {MAT }} / \mathrm{D}_{\mathrm{TOT}}$ & $18.089 *$ & $0.000 *$ & $0.871 *$ & $0.000^{*}$ \\
\hline & $\mathrm{CL}_{\mathrm{M}}$ & - & - & $0.943^{*}$ & $0.005^{*}$ \\
\hline & $\mathrm{CL}_{\mathrm{F}}$ & - & - & $1.000 *$ & $0.000 *$ \\
\hline
\end{tabular}



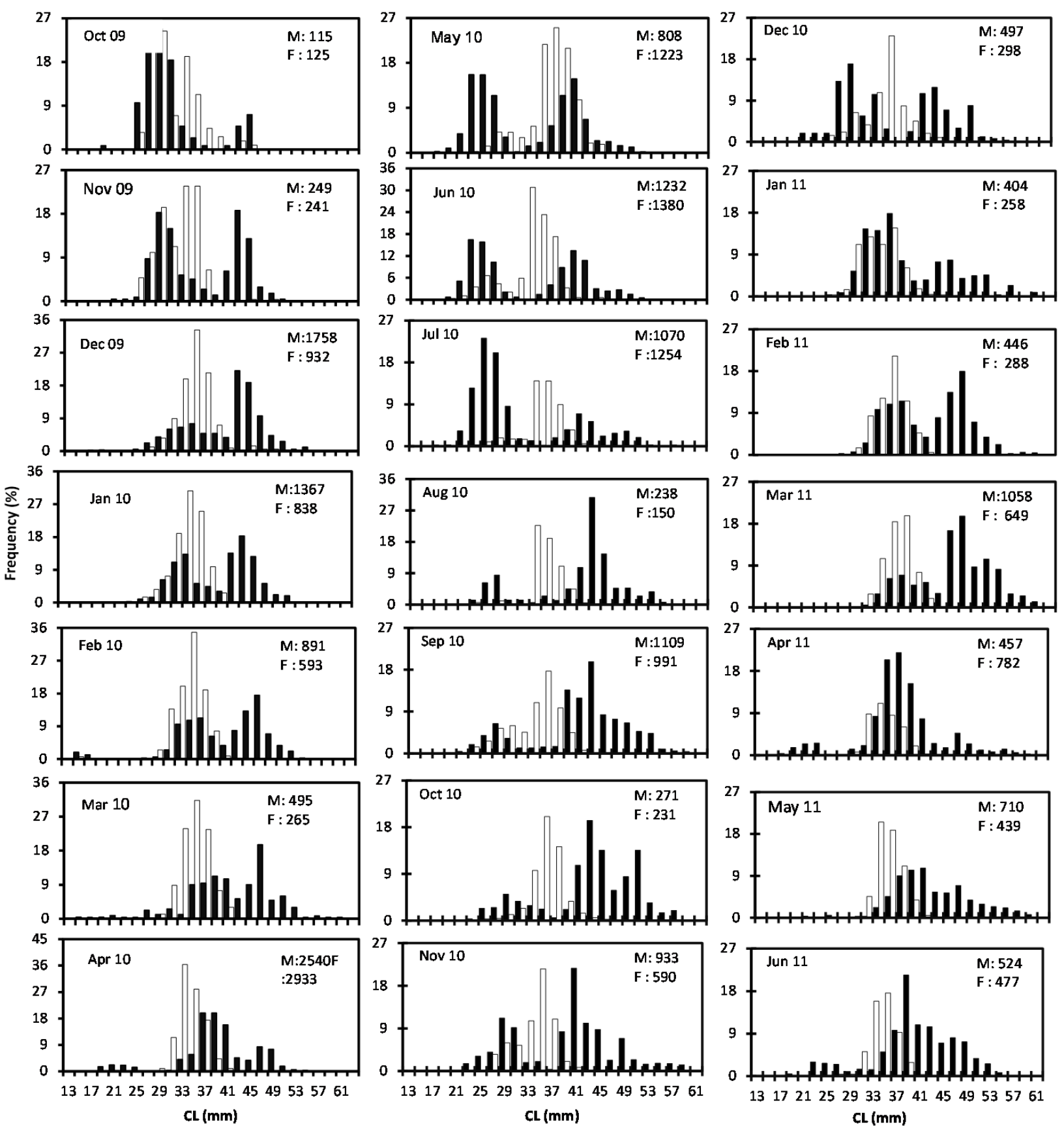

Figure 1. Monthly standardized carapace length-frequency distributions (SLFD) by sex of $A$. foliacea sampled during the DEEP (from October 09 to June 10) and STRATUM (from July 10 to June 11) surveys (Black histograms, female; White histograms, males).

survey, $A$. foliacea juveniles were collected from 26 of the 53 hauls and only $8.1 \%$ of the population were identified as juveniles. Density values of the recruits (DREC) were between 13 and $3265 \mathrm{n} \mathrm{km}^{-2}$. The recruits were available between 400-699 m depth, and \%85 of them were located only at two stratums (500 and 600 $\mathrm{m}$ ) (Figure 4a). The lowest mean $\mathrm{D}_{\text {REC }}$ values observed in March (243 $\mathrm{n} \mathrm{km}^{-2}$ ), highest value was observed in July $\left(1441 \mathrm{n} \mathrm{km}^{-2}\right.$ ). Only for 5 hauls, $D_{\text {REC }} / D_{\text {TOT }}$ fraction found to be higher than 0.30. For the DEEP survey, mean DREC value was $563 \mathrm{n} \mathrm{km}^{-2}$ and $14.2 \%$ of the individuals was recruits (Table 1 ). While monthly differences found to be a factor impacting both $D_{\text {REC }}(F=2.266, p=0.038)$ index and the $D_{\text {REC }} / D_{\text {TOT }}$ fraction, season has no impact. Both $D_{\text {REC }}(r=-0.618, p=0.000)$ and $D_{\text {REC }} / D_{\text {TOT }}(r=-0.655$, $p=0.000$ ) displayed a negative correlation with the depth stratum (Figure 4b; Table 2).

The mean sex ratios of $A$. foliacea for the DEEP and STRATUM surveys were 0.50 and 0.49 , respectively, therefore the hypothesis of a 1:1 was accepted $\left(\chi^{2}=\right.$ $0.160 ; P>0.05)$. Season and depth were not significant factors on the SR, and didn't displayed statistically significant correlation at the 0.05 level (Table 2).

The gonadosomatic index (GSI) of $550 \mathrm{~A}$. foliacea females (mean $\mathrm{CL}=43.5 \mathrm{~mm}$; $\min -\max =38-59 \mathrm{~mm}$ ) was evaluated through 14-month period (Figure 5a). A sharp 


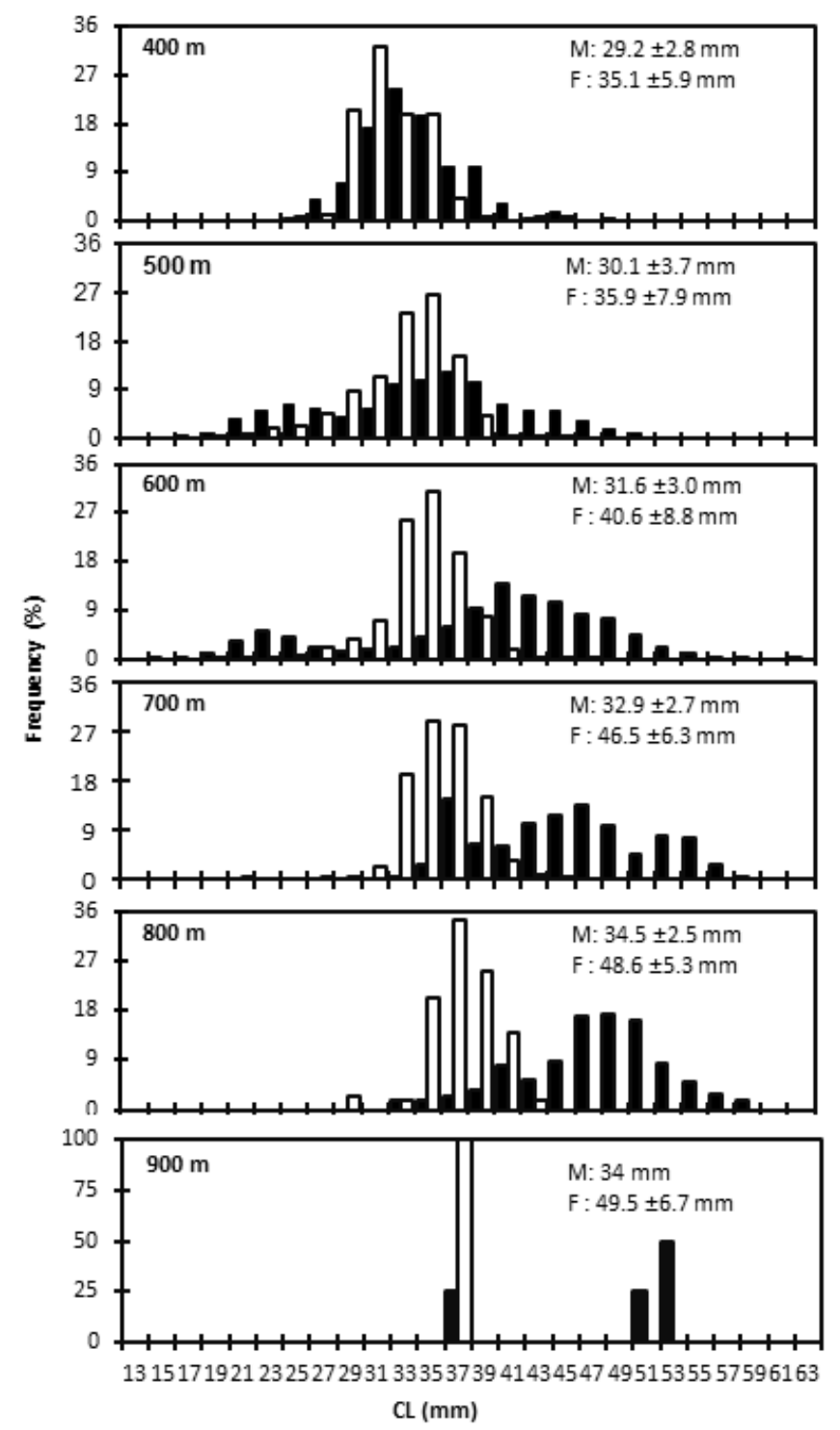

Figure 2. Standardized carapace length-frequency distributions (SLFD) of $A$. foliacea sampled from the STRATUM survey by depth strata (Black histograms, female; White histograms, males).

increase was observed in May this trend continued until August. The GSI value was decreased sharply in September until to the May. The spawning pattern of the females occurred as unimodal between June and August. Following the detection of first mature female (Stage III and IV) in June, data indicated that only $20 \%$ of females were remained immature (Stage I and II) in August. First appearance of the partially spent individuals was also in June (5.2\%) and $43 \%$ of females were spent in August (Figure 5b). In the REPR survey (July-August), based on the proportion of fully mature gonads (stage III and IV) by every two $\mathrm{mm}$ size class in CL (between 22 and $62 \mathrm{~mm}$ ), the first maturation size (FMS: carapace length at which $50 \%$ of the individuals is mature) was estimated $38.7 \approx 39 \mathrm{~mm}$ (1.8 years old) for females (Figure 5c).

Mature female $(C L \geq 38 \mathrm{~mm})$ and male $(C L \geq 34 \mathrm{~mm})$ individuals of $A$. foliacea constitutes more than half $(53 \%)$ of the total population in the Antalya Bay. Density of the mature individuals (pooled sex; DMAT) and

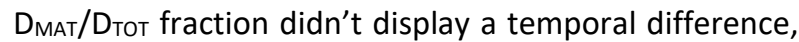
however stratum had impact on both $\mathrm{D}_{\mathrm{MAT}}(p=0.007)$ and $\mathrm{D}_{\text {MAT }} / \mathrm{D}_{\text {Tот }}(p=0.000)$ indices (Table 2$)$. Mature individuals distributed in all the depths $\geq 400 \mathrm{~m}$ with highest availability in both 500 and $600 \mathrm{~m}$ stratums (Table 1, Figure 4c). The DMAT value displayed an insignificant negative correlation with depth ( $r=-0.243)$. However, a strongly positive correlation between $\mathrm{D}_{\text {MAT}} / \mathrm{D}_{\text {TOT }}$ fraction and depth was detected (Table 2) and percentage of the mature reached to $85 \%$ at the $800 \mathrm{~m}$ depth (Figure 4d; Table 1).

Two methods (ELEFAN and Modal progression Analaysis) and two different computer package (LFDA 5.0: Kirkwood, Aukland \& Zara, 2001 and FISAT II: Gayalino, Sparre \& Pauly, 2002) were used to estimate the growth parameters and mortality rates (Table 4). According to the reproduction pattern of the A. foliacea, $1^{\text {th }}$ of August was adopted conventional birthday in the 


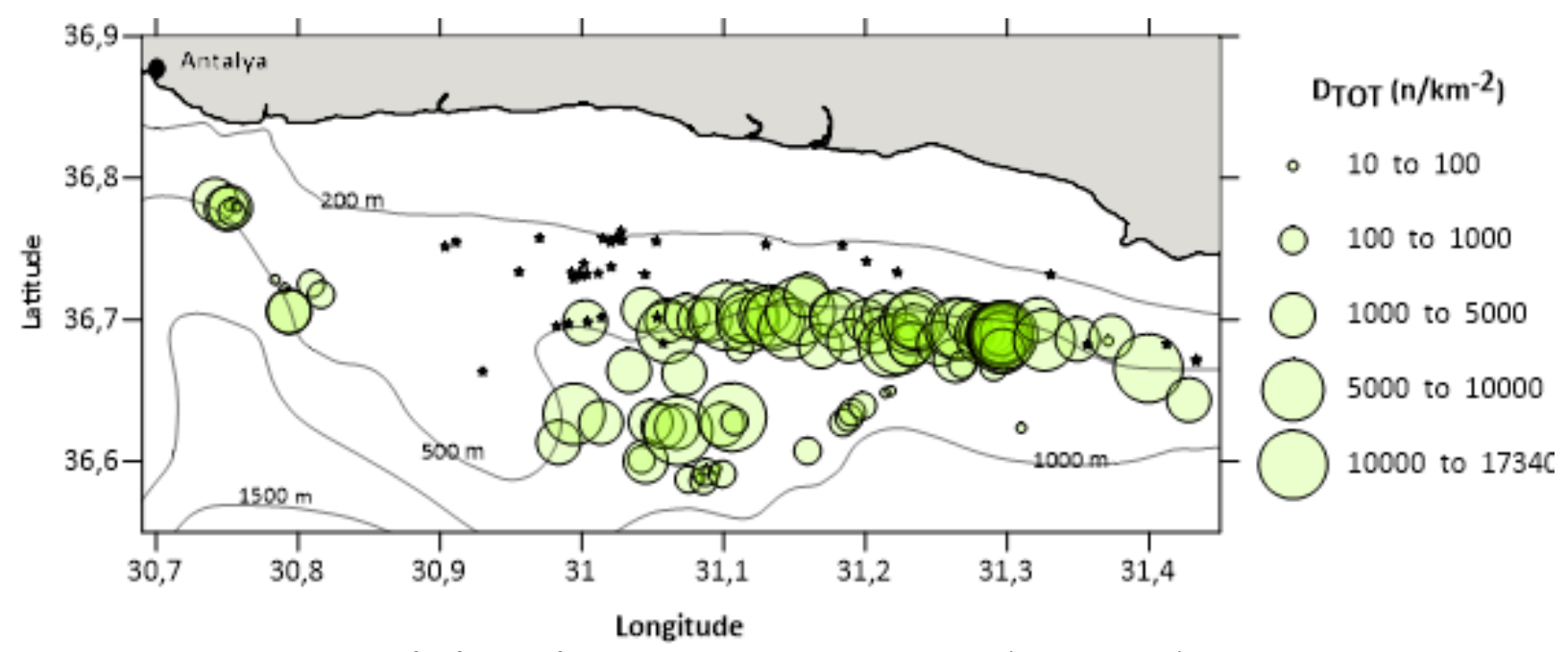

Figure 3. Overall density index of A.foliacea from all three surveys in Antalya Bay (*, empty haul).

Table 3. Correlated species with A.foliacea and their occurrence in hauls (\%). Correlations are statistically significant at the $p \leq$ $0.05\left(^{*}\right)$ and at the $p \leq 0.01\left(^{* *}\right)$ levels.

\begin{tabular}{lccccc}
\hline Class & Family & Oc(\%) & $\mathrm{r}$ & $\mathrm{p}$ \\
\hline Crustacea & Polychelidae & Polycheles typhlops (Heller, 1862) & 73 & $0.546^{* *}$ & 0.000 \\
& Aristeidae & Aristeus antennatus (Risso, 1816) & 65 & $0.600^{* *}$ & 0.000 \\
& Pandalidae & Plesionika martia (A. Milne-Edwards, 1883) & 56 & $0.667^{* *}$ & 0.000 \\
& Pandalidae & Plesionika acanthonotus (Smith, 1882) & 25 & $0.398^{* *}$ & 0.001 \\
Actinopterygii & Macrouridae & Nezumia aequalis (Günther, 1878) & 76 & $0.620^{* *}$ & 0.000 \\
& Trachichthyidae & Hoplostethus mediterraneus Cuvier, 1829 & 75 & $0.311^{*}$ & 0.013 \\
& Myctophidae & Lampanyctus crocodilus (Risso, 1810) & 62 & $0.428^{* *}$ & 0.000 \\
& Stomiidae & Stomias boa (Risso, 1810) & 56 & $0.408^{* *}$ & 0.001 \\
& Nettastomatidae & Nettastoma melanurum (Rafinesque, 1810) & 49 & $0.318^{*}$ & 0.011 \\
Chondrichthyes & Etmopteridae & Etmopterus spinax (Linnaeus, 1758) & 70 & $0.429^{* *}$ & 0.000 \\
& Centrophoridae & Centrophorus granulosus (Bloch \& Schneider, 1801) & 30 & $0.254^{*}$ & 0.045 \\
Brachiopoda & Terebratulidae & Gryphus vitreus (Born, 1778) & 71 & $0.285^{*}$ & 0.024 \\
\hline
\end{tabular}
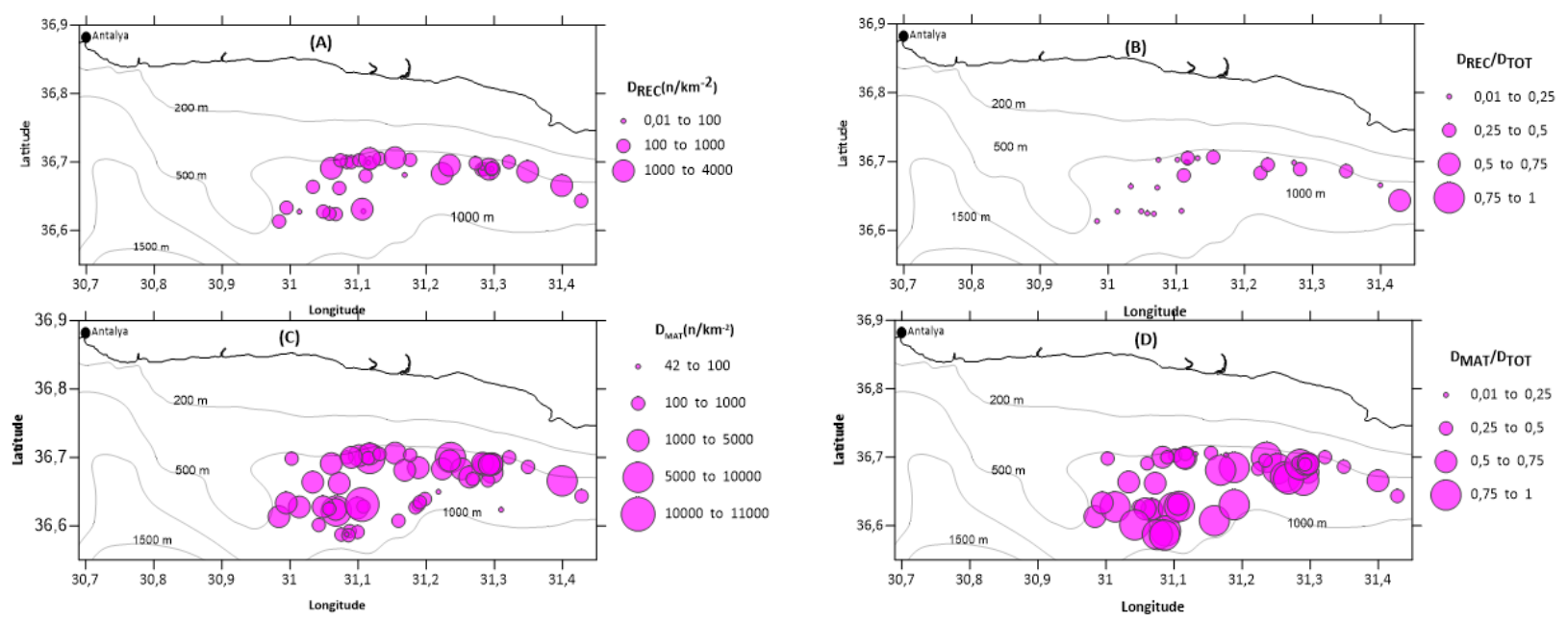

Figure 4. a) The recruit ( $D_{\text {REC }}$ ) and (b) mature $\left(D_{\text {MAT }}\right)$ indices, (c) recruitment ( $\left.D_{\text {REC }} / D_{\text {TOT }}\right)$ and $(d)$ mature $\left(D_{\text {REC }} / D_{\text {TOT }}\right)$ fractions of $A$. foliacea from the STRATUM survey. 

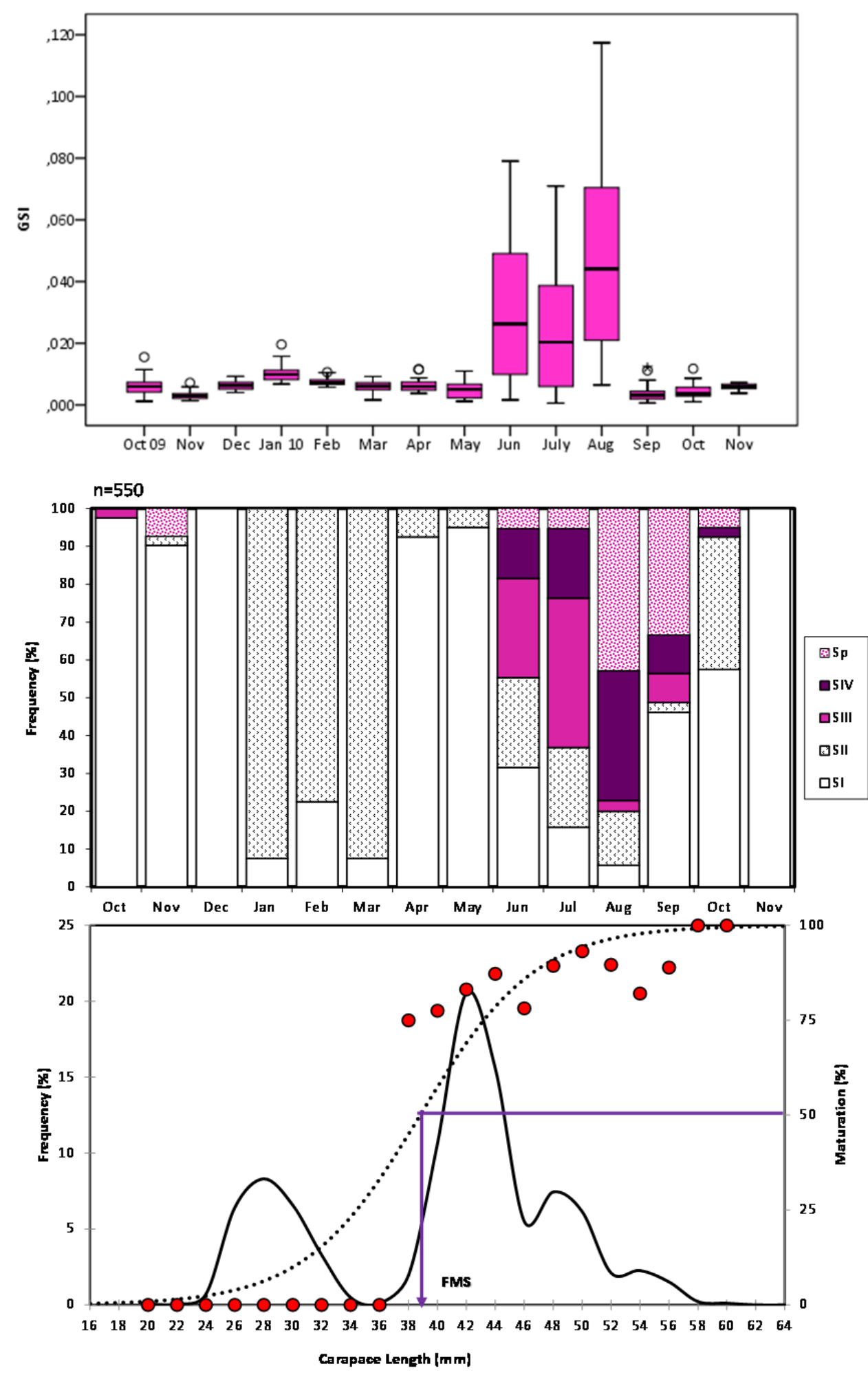

Figure 5. a)-Changes in GSI of standard size ( $C L \geq 40 \mathrm{~mm}$ length) of female A.foliacea, b)-Monthly development in relative frequency of $A$.foliacea maturity stages, c)-The first maturation $\left(C L_{50 \%}\right)$ sizes for female specimens.

length-at-age key. Identification of the modal groups for females was easier than males. Examining the general pattern revealed maximum 3-year modes for males and 5 -year modes for females displayed. As a result of low number of identifiable cohorts of males, exploitation and mortality were analyzed only for females. Mean CLs of the modal group of 5 cohorts of female $A$. foliacea were represented in Figure 6. Employing the parameters of growth functions, the $\mathrm{CL}$ attained by the female red shrimps at years 1-5 of its life span works out to be 28 , $41,49,55$ and $58 \mathrm{~mm}$, respectively. The growth performance index $\phi$ of $A$. foliacea was calculated as 
Table 4. The seasonal and non-seasonal growth curve parameters obtained for female $A$. foliacea by using ELEFAN and Modal progression Analysis (MPA) in two different software FISAT II and LFDA 5.0. (Parameters in the Von Bertalanffy growth equations (VBGF), $L_{\infty}$ : asymptotic length, $K$ : curvature parameter, $t_{0}$ : the "age" fish would have had at length zero if they had always grown according to the VBGF, $C$ : parameter expressing the amplitude of seasonal growth oscillation in the VBGF, $\mathbf{t}_{\mathbf{s}}$ : parameter of the seasonally oscillating version of the VBGF, WP: the time of the year when growth rate is slowest; equivalent to $t_{s}+0.5$ year)

\begin{tabular}{|c|c|c|c|c|c|c|}
\hline \multirow{4}{*}{$\begin{array}{l}\text { Software } \\
\text { Model } \\
\text { Growth curve } \\
\text { Survey }\end{array}$} & \multicolumn{3}{|c|}{ FISAT II } & \multirow{2}{*}{\multicolumn{2}{|c|}{$\begin{array}{c}\text { LFDA } 5.0 \\
\text { ELEFAN }\end{array}$}} & \\
\hline & \multicolumn{2}{|c|}{ ELEFAN } & \multirow[t]{2}{*}{ MPA } & & & \\
\hline & \multicolumn{2}{|c|}{ Non-seasonal } & & \multicolumn{2}{|c|}{ Seasonal } & \\
\hline & Deep & Stratum & Both & Deep & Stratum & Mean \\
\hline $\mathrm{L}_{\infty}$ & 66.2 & 66.2 & 65.4 & 63.9 & 64.3 & 65.2 \\
\hline K & 0.45 & 0.45 & 0.47 & 0.45 & 0.49 & 0.46 \\
\hline$t_{0}$ & - & - & -0.10 & -0.25 & -0.23 & -0.19 \\
\hline C & - & - & - & 0.40 & 0.32 & 0.36 \\
\hline$t_{s}$ & - & - & - & 0.46 & 0.48 & 0.47 \\
\hline
\end{tabular}

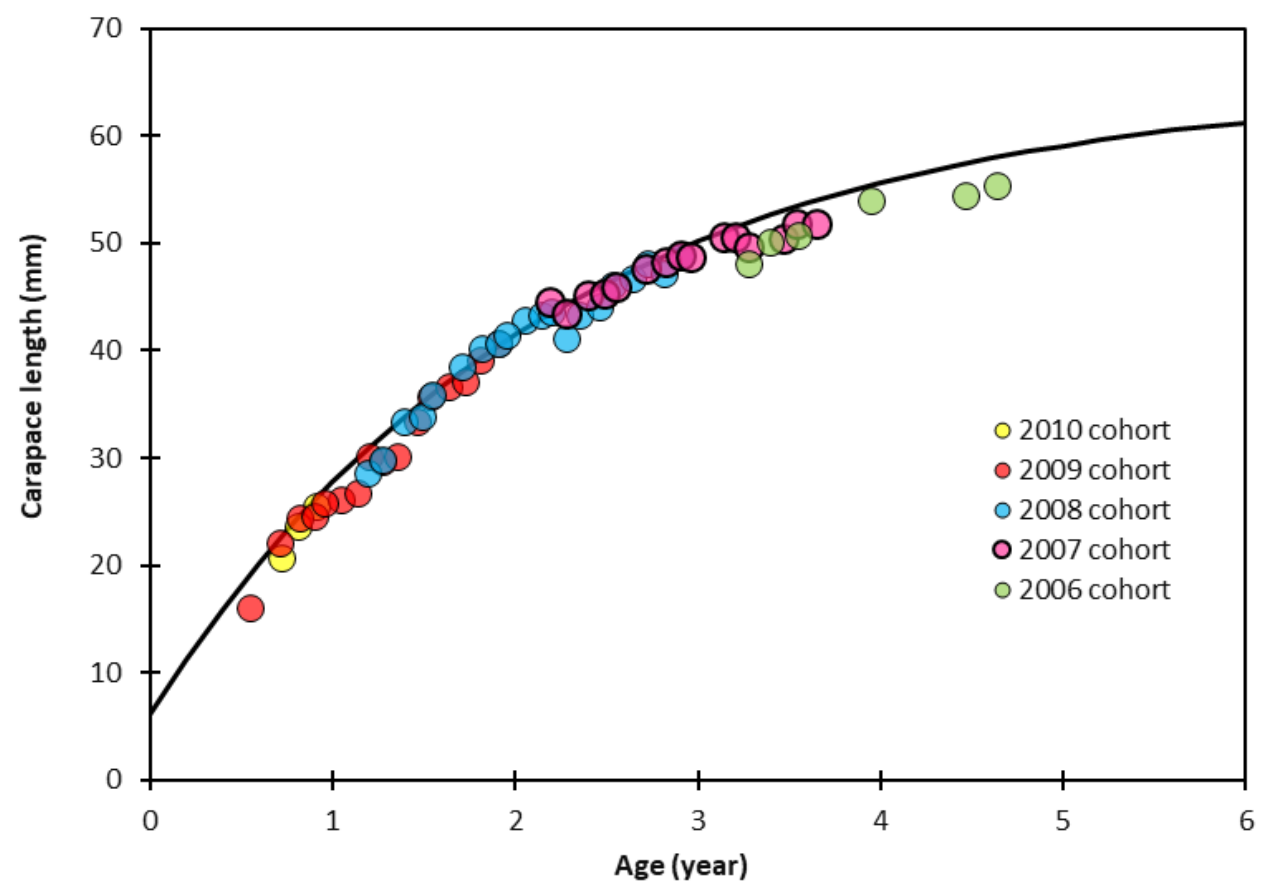

Figure 6. Five identified cohorts based on modal progression analysis and non-seasonal growth model for A.foliacea in the Antalya Bay.

3.299. Using the pooled data sets, males ( $\mathrm{t}=14.91)$ and females ( $\mathrm{t}=47.869)$ of $A$. foliacea exhibited a strong negative allometric growth:

$$
\begin{array}{ll}
\text { Male: TW }(g)=0.0014 * \mathrm{CL}(\mathrm{mm})^{2.615} & \mathrm{r}^{2}=0.95 \\
\text { Female: TW }(\mathrm{g})=0.0014 * \mathrm{CL}(\mathrm{mm})^{2.583} & \mathrm{r}^{2}=0.95
\end{array}
$$

Commercially available 44DM codend, retention was almost full (98.4\%) and $78 \%$ of retained individuals were smaller than FMS (first maturity size) (Figure 7a). Even though retention of $A$. foliacea decreased from $98.4 \%$ to $86 \%$ after changing the diamond shaped codend with square shaped codend (44SM), most of the retained individuals (77\%) were still smaller than FMS (Figure 7b). Moreover, an increase in $\mathrm{CL}_{50}$ (carapace length at which $50 \%$ of the catch is retained in the codend) from 18.8 to $22.2 \mathrm{~mm}$. CL50 values estimated for both codends were much lower than first maturity size for $A$. foliacea. According to estimated $\mathrm{CL}_{50}$ and $\mathrm{FMS}$ values, the exploitation of the giant red shrimp begins in the first juvenile stage.

The total mortality ( $Z$ ) was calculated as; 1.484 year $^{-1}$ from Length Converted Catch Curve method (Pauly, 1984), 1.440 year $^{-1}$ from Beverton-Holt method (Beverton \& Holt, 1956) and 1.394 year $^{-1}$ from PowellWetherall method (Powell, 1979) the with the algorithms integrated LFDA5.0 software. The natural mortality (M) (Pauly, 1980) calculated as 0.591 year $^{-1}$. An average $Z$ value (1.439 year $^{-1}$ ) used for the further computations. The fishing mortality $\left(\mathrm{F}_{\text {curr }}=\mathrm{Z}-\mathrm{M}\right)$ and the exploitation ratio $(E=F / Z)$ was estimated as 0.848 year $^{-1}$ 

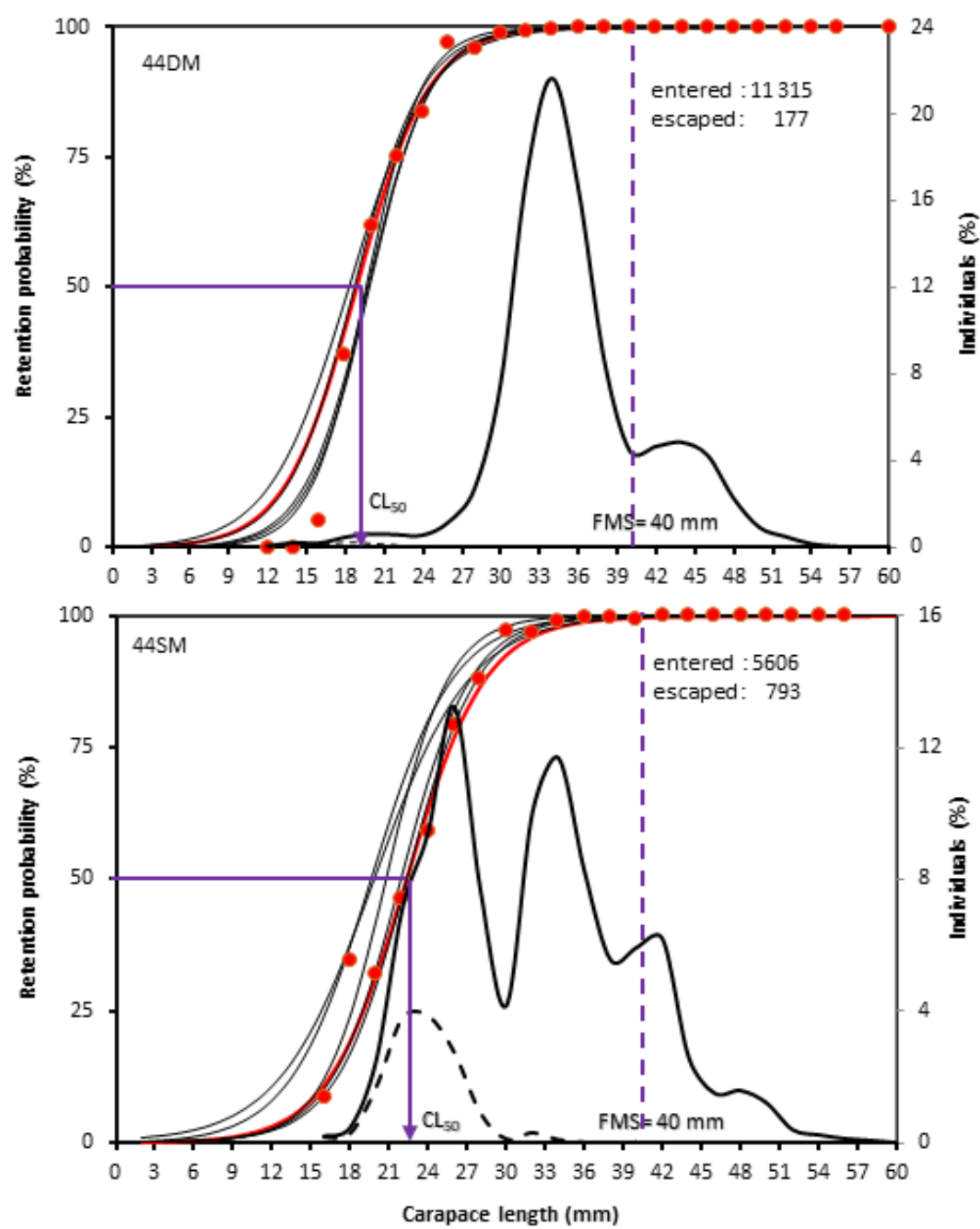

Figure 7. Selection curves with $\mathrm{CL}_{50}$ values for two codends, and carapace length frequency distributions of $A$. foliacea that entered (thick line) and escaped (broken line).

and 0.589 year $^{-1}$ respectively. The coefficient of reference points of the fishing mortality was calculated as 0.540 year $^{-1}$ for $F_{0.1}$, while the value was calculated as 0.960 year $^{-1}$ for $F_{\max }$, with the Yield software (Branch, Kirkwood, Nicholson, Lawlor \& Zara, 2000). Since current level of fishing mortality $\left(F_{\text {cur }}=0.848\right.$ year 1$)$ is higher than $\mathrm{F}_{0.1}$ and too close to $\mathrm{F}_{\max }$, the stock of $A$. foliacea females was considered in fully exploited status in the Antalya Bay, and stock had a potential for the growth overfishing.

\section{Discussion}

Although stock status is well known for the giant red shrimp $A$. foliacea in western and central Mediterranean areas, there is a data gap in the Eastern Mediterranean. This study delivered detailed information on the biological patterns of the species from the most eastern part of the Mediterranean, and it provided data for a better comparison status of the stocks in the different parts of the Mediterranean.

The maximum $\mathrm{CL}$ of the giant red shrimp's females in the Mediterranean Sae reported as $74 \mathrm{~mm}$ at the
Strait of Sicily and that of males $58 \mathrm{~mm}$ at Tyrrhenian and Aegean Seas (Cau et al., 2002), individuals sampled from the study area with in the current study were bigger than $66 \mathrm{~mm}$ and $52 \mathrm{~mm}$ (Table 5). Although in most of the studies carried out in the western and central Mediterranean, $A$. foliacea was reported to distribute intensely between 500 and 800 m (Table 5), moreover the species found also at the upper parts of the slope (201-500 m) (D'Onghia et al., 1994; Yahiaoui, 1994). In the present study the species was mostly caught in depth of 500-600 m. According to the Rinelli et al. (2013), based on the analysis of MEDITS surveys in seven Mediterranean Geographical Sub-Areas, the mean $\mathrm{BI}$ and $\mathrm{D}_{\text {Tот }}$ indices recorded for $A$. foliacea show the highest values in southern Sicily-Maltese Islands $\left(24.5 \mathrm{~kg} \mathrm{~km}^{-2}\right)$, eastern Ionian Sea $\left(20.1 \mathrm{~kg} \mathrm{~km}^{-2}\right)$ and the southern Tyrrhenian Sea $\left(17.3 \mathrm{~kg} \mathrm{~km}^{-2}\right)$. The highest Dтот value was recorded in the eastern Ionian Sea, (1408 n $\mathrm{km}^{-2}$ ), followed by the southern Tyrrhenian Sea (1222 $\mathrm{n}$ $\mathrm{km}^{-2}$ ) and southern Sicily-Maltese Islands (1021 $\left.\mathrm{n} \mathrm{km}^{-2}\right)$. A surprisingly high Dтот and BI values $\left(5000 \mathrm{n} \mathrm{km}^{-2}\right.$ and $95 \mathrm{~kg} \mathrm{~km}^{-2}$ at $600 \mathrm{~m}$ depth stratum) were reported in the Eastern Ionian Sea (in null exploitation condition) 
(Politou et al., 2004). Rinelli et al. (2013) indicated that "the results of MEDIT surveys allowed to conclude that there are no clear, evident gradients for the distribution and abundance of $A$. foliacea species". On the contrary, Cau et al. (2002) and Politou et al. (2004) observed "a longitudinal gradient of the space distribution of the $A$. foliacea was relatively more abundant in the central and easternmost part than the westernmost Mediterranean Sea". The estimated BI and Dтот values $\left(80 \mathrm{~kg} \mathrm{~km}^{-2}\right.$ and $5100 \mathrm{n} \mathrm{km}^{-2}$ ) indicated that there was an increasing abundance gradient at $500 \mathrm{~m}$ stratum, from the western to the eastern Mediterranean, of the species was confirmed with the present study.

In different parts of the Mediterranean Sea, the SR can vary between areas, depth and season, and have been reported between 0.73 in North Ligurian Sea (AAVV, 2008) and 0.46 in the South Aegean Sea (Cau et al., 2002). The SR value in Antalya Bay was 1:1 and within these limits.

Several species (Table 3) were identified as "plausible indicator species" of the giant-red shrimp habitat in the present study. Previously A. antennatus, Polycheles typhlops, Hymenocephalus italicus and Etmopterus spinax were also reported as a companion species to the $A$. foliacea within other studies (De Santis, S., Labate, Tursi, D’Onghia, \& Maiorano, 1999; Righini \& Abella, 1994; Sardà \& Demestre, 1989) .

The reproductive period of female $A$. foliacea in the Antalya Bay (Figure 5a-b) was similar with available information on the species (Table 6), and in general, mature females can be found between May and September in different part of Mediterranean (Mura et al., 1992; Papaconstantinou \& Kapiris, 2003). Mature specimens have been caught at depths between 440 to 800 m (Kapiris \& Thessalou-Legaki, 2009; Palmas et al., 2014) in the Mediterranean Sea. The smallest mature female and first maturity size measured $33 \mathrm{~mm}$ (D'Onghia et al., 1998) and $36 \mathrm{~mm}$ (Mura et al., 1992), respectively. The estimated first maturity size $(39 \mathrm{~mm}$ $\mathrm{CL}$ ) in the Antalya Bay (Figure $5 \mathrm{c}$ ) was very similar with D'Onghia et al. (1994) and Kapiris \& Thessalou-Legaki (2009) (Table 6).

The recruitment of juveniles of $A$. foliacea occurs mostly between 400 and $600 \mathrm{~m}$ depth range in western and central Mediterranean (Mura et al., 1992; Ragoneze \& Bianchini, 1995; Belcari et al., 2003; Ragonese et al., 2004) in spring when individuals have reached a carapace length between $8 \mathrm{~mm}$ ( $D^{\prime}$ Onghia et al., 1998) and $31 \mathrm{~mm}$ (Ragonese et al., 1994). The recruits can be found in earlier months, as in the Tyrrhenian Sea and in Ionian Sea from January to March (D'Onghia et al., 1998). Based on MEDITS and GRUND surveys, the highest $D_{R E C}$ value was recorded in the Central Tyrrhenian Sea $\left(1979 \mathrm{n} \mathrm{km}^{-2}\right)$ in while the lower values (1-91 $\mathrm{n} \mathrm{km}^{-2}$ ) was reporter from the northern Ligurian Sea. A positive trend was only observed in the Western Ionian Sea (37-870 $\mathrm{n} \mathrm{km}^{-2}$ ) (AAVV, 2008). In the Eastern Ionian Sea, the recruit juveniles were found during only six years (11-294 $\mathrm{n} \mathrm{km}^{-2}$ ). Most of the $A$. foliacea recruitment was found to be take placed from April to the August and more than $90 \%$ of recruits dwell at 500 600 stratums and undertake ontogenetic migrations to lower grounds (700-800 m) in the Antalya Bay. Recruit juveniles were never found areas deeper than $700 \mathrm{~m}$.

Estimated Von Bertalanffy parameters of female $A$. foliacea (Figure 6) in the present study were generally similar to those presented previously in the literature in the Mediterranean Sea (Table 6). The highest $\mathrm{CL}_{\infty}$ was recorded in eastern Ionian Sea (74 $\mathrm{mm}$, D'Onghia et al., 1994) and in the south Tyrrhenian Sea (73 mm; AAVV, 2008). In the south Aegean (Cau et al., 2002) and in the eastern Aegean Seas (AAVV, 2008) was reported smallest $\mathrm{CL}_{\infty}(62 \mathrm{~mm}$ ) value. Generally, four and five age groups were identified (Table 6), with the exception of in Ionian Sea (AAVV, 2008; Papaconstantinou \& Kapiris, 2003) where three age groups were detected. However, six age groups also reported in Algerian (Yahiaoui, 1994) and Sicilian waters (Cau et al., 2002).

The observed $\mathrm{CL} \% 50$ values of both the commercial $(19 \mathrm{~mm})$ and alternative square mesh $(22 \mathrm{~mm})$ codends were smaller than first maturity size $(39 \mathrm{~mm})$ of the species (Figure 7a-b). FMS of the species known to range between $36 \mathrm{~mm}$ (Mura et al., 1992) and $43 \mathrm{~mm}$ (D’Onghia et al., 1998). Our results indicate that similar to the estimations of other studies, $16 \mathrm{~mm}$ (Carlucci et al., 2006) and 23.2 (Deval et al., 2016), carried out in the Mediterranean Sea, large amounts of juveniles were retained in codends.

According to the GRUND and MEDIT surveys (AAVV, 2008), $Z$ values was fluctuated between 0.43 year $^{-1}$ and 2.83 year $^{-1}$ for different regions and annually. Observations indicated over exploitation of the stocks (E>0.5) in Tyrrhenian and in Sardinian Seas. With an exception of eastern Ionian Sea, status change from the full exploited to an overexploitation of the $A$. foliacea stocks is evident for the areas evaluated (the Western Ionian Sea, the South Sicily and Maltase islands) by similar studies. In the Eastern Ionian Sea, status of the $A$. foliace was reported as underexploited, since the fishing pressure was almost zero in the area (AAVV, 2008). In Mersin Bay, Demirci (2006) suggested a higher $M$ and a lower exploitation (E) values probably using the higher surface water temperature $\left(21{ }^{\circ} \mathrm{C}\right)$ instead of lover bottom temperature $\left(14{ }^{\circ} \mathrm{C}\right)$.

In concussion, juvenile individuals of $A$. foliacea with no economic value in the Antalya Bay "is caught before reaching the maximum reproductive potential, similar with other regions of Mediterranean" (Belcari et al., 2003). The exploitation of the juvenile part of the stock before it has reached its full biological and economic potential, defined as growth overfishing (Diekert, 2015). Enforcing the increased legal mesh size (at present, $44 \mathrm{~mm}$ diamond) should be the first step of controlling the overfishing, for the benefit of both the fishermen and the marine environment. Also the results of previous selectivity study on $A$. foliacea carried out in the Antalya Bay indicated that, \%50 retention CL were 22 and $23 \mathrm{~mm}$ for $50 \mathrm{~mm}$ diamond and $90^{\circ}$ turned codends 


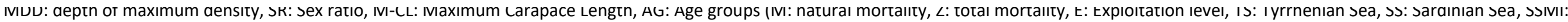
South Sicily and Maltese Island, IS: Ionian Sea, S-AS: South Aegean Sea, MB: Mersin Bay, AB: Antalya Bay)

\begin{tabular}{|c|c|c|c|c|c|c|c|c|c|c|c|c|c|c|c|c|c|c|}
\hline Area & SD & MDD & Dтот & $\mathrm{BI}$ & SR & Sex & $\mathrm{M}-\mathrm{CL}$ & $C L_{\infty}$ & $K$ (year) & $t_{0}$ & $\phi^{\prime}$ & AG & $\mathrm{M}$ & Z & $\mathrm{E}$ & $\mathrm{a}$ & $\mathrm{b}$ & References \\
\hline \multirow[t]{2}{*}{ Algeria } & $1979-88$ & $400-600$ & - & - & - & q & 67 & 73 & 0.56 & - & 3.47 & 6 & - & 0.91 & $0.6-0.7$ & - & - & Yahiaoui, 1994 \\
\hline & & & & & & $0^{\pi}$ & 45 & 45 & 0.66 & - & 3.13 & 5 & - & 0.79 & - & - & - & \\
\hline \multirow[t]{2}{*}{ TS } & 1994-04 & $500-800$ & 1644 & 27.8 & 0.50 & q & 71 & 72 & 0.44 & -0.10 & 3.36 & 4 & 0.50 & $0.83-2.16$ & $0.52-0.68$ & 0.002 & 2.502 & AAVV, 2008 \\
\hline & & & & & & $0^{x}$ & & 45 & 0.66 & -0.25 & 3.13 & & - & - & - & - & - & \\
\hline \multirow[t]{4}{*}{ SS } & 1994-99 & $500-800$ & - & 20.9 & 0.66 & q & 70 & 71 & 0.54 & 0.27 & 3.43 & - & - & - & - & - & - & Cau et al., 2002 \\
\hline & 1994-04 & $500-800$ & 2359 & 37.8 & 0.53 & q & 79 & 72 & 0.50 & 0.00 & 3.42 & 5 & 0.50 & $0.86-2.44$ & $0.39-0.83$ & 0.002 & 2.546 & AAVV, 2008 \\
\hline & $1990-93$ & $500-700$ & - & - & - & q & 57 & 65 & 0.67 & 0.28 & 3.45 & 4 & 0.42 & $0.65-0.79$ & 0.38 & 0.003 & 2.437 & Ragonese et al. 1994b \\
\hline & & & & & - & $0^{n}$ & 39 & 41 & 0.96 & 0.28 & 3.21 & 5 & & & & 0.001 & 2.948 & \\
\hline \multirow[t]{6}{*}{ SSMI } & & & & 21.1 & 0.55 & q & 74 & 65 & 0.67 & - & 3.45 & 6 & - & - & - & - & - & Cau et al., 2002 \\
\hline & 1994-04 & $500-800$ & 535 & 12.9 & 0.51 & q & 74 & 62 & 0.65 & 0.05 & 3.40 & 5 & 0.50 & $0.47-1.24$ & $0.02-0.56$ & 0.002 & 2.507 & AAVV, 2008 \\
\hline & & & & & & $0^{n}$ & - & 40 & 0.79 & -0.44 & 3.11 & 4 & - & - & - & - & - & \\
\hline & - & - & - & & - & q & 72 & 74 & 0.50 & 0.09 & 3.44 & - & - & - & - & - & - & D’Onghia et al., 1994 \\
\hline & - & $500-600$ & - & - & - & 웅 & 62 & 64 & 0.46 & - & 3.27 & 3 & - & - & - & - & - & Papaconstantinou and Kapiris, 2003 \\
\hline & & & & & - & $0^{\pi}$ & 40 & 47 & 0.56 & - & 3.09 & 2 & - & - & - & - & - & \\
\hline \multirow{5}{*}{ IS } & 2001 & $600-800$ & 1694 & 54.9 & 0.57 & \% & 62 & 67 & 0.37 & -0.11 & 3.21 & 5 & - & - & - & - & - & Politou et al. 2004 \\
\hline & & & & & 0.43 & $0^{x}$ & 49 & 47 & 0.45 & -0.42 & 3.00 & 3 & - & - & - & - & - & \\
\hline & & & 1051 & 13.5 & 0.54 & 웅 & 69 & 71 & 0.49 & 0.00 & 3.38 & 3 & 0.50 & $0.46-1.53$ & $0.10-0.67$ & 0.001 & 2.646 & \\
\hline & 1994-04 & $500-800$ & 1408 & 20.1 & 0.52 & q & 58 & 62 & 0.56 & 0.16 & 3.33 & 4 & 0.50 & $0.43-0.72$ & $0.12-0.31$ & - & - & AAVV, 2008 \\
\hline & & & & & 0.48 & $0^{x}$ & - & 46 & 0.34 & -1.22 & 2.86 & 3 & - & - & - & - & - & \\
\hline S-AS & 1994-99 & $500-800$ & 451 & 12.7 & 0.46 & q & - & 62 & 0.60 & -0.34 & 3.36 & - & - & - & - & - & - & Cau et al., 2002 \\
\hline \multirow[t]{2}{*}{$M B$} & 2005 & $400-800$ & - & 67.3 & 0.67 & q & - & 63 & 0.66 & -0.47 & 3.42 & 4 & 0.94 & 1.373 & 0.31 & 1.039 & 2.330 & Demirci, 2006 \\
\hline & & & & & 0.33 & $0^{n}$ & - & 48 & 0.33 & -0.59 & 2.88 & 3 & & & & 1.378 & 2.022 & \\
\hline \multirow[t]{2}{*}{$A B$} & 2009-12 & $500-600$ & 4508 & 76.3 & 0.49 & $q$ & 66 & 65 & 0.46 & -0.19 & 3.29 & 5 & 0.59 & 1.439 & 0.59 & 0.0014 & 2.615 & Present study \\
\hline & & & & & 0.51 & $0^{\pi}$ & 52 & - & - & - & - & 3 & - & - & - & 0.0014 & 2.583 & \\
\hline
\end{tabular}

Table 6. Results of the two-way MANOVA and non-parametric Spearman's rho correlation analysis for significant testing in all biological indices and fractions $\left(\right.$ Total density $\left(\mathrm{D}_{\text {TOT, }} \mathrm{n} \mathrm{km}{ }^{-2}\right)$, biomass $\left(\mathrm{Bl}\right.$, $\left.\mathrm{kg} \mathrm{km}^{-2}\right)$, density of recruit $\left(D_{\text {REC }}, n k^{-2}\right)$, male $\left(D_{M}, n k^{-2}\right)$, female $\left(D_{F}, \mathrm{n} \mathrm{km}^{-2}\right)$ and mature $\left(D_{\text {MAT }}, \mathrm{n} \mathrm{km}^{-2}\right)$ and CPUE $\left(\mathrm{kg} \mathrm{h}^{-1}\right)$ indices, $D_{\mathrm{REC}} / D_{\text {TOT }}$ and $D_{\text {MAT }} / D_{\text {TOT }}$ fractions, Sex ratio $(\mathrm{SR})$, mean carapace length $(C L$, mm) and body weight (TW, g) of $A$. foliacea, between strata and seasons. * are significant at the 0.01 level.

\begin{tabular}{|c|c|c|c|c|c|}
\hline Area & References & Spawning season & SMF (mm) & $\mathrm{CL}_{50}$ & Recruitment \\
\hline Sardinia waters & Mura et al., 1992 & - & - & 36 & Spring \\
\hline Central Tyrrhenian Sea & Belcari et al., 2003 & July-September & - & 41 & Spring \\
\hline Strait of Sicily & Ragoneze and Bianchini,1995 & Spring-Summer & - & 40 & Spring \\
\hline Strait of Sicily & Ragonese et al., 2004 & - & - & 42 & Spring \\
\hline Western Ionian Sea & D’Onghia et al., 1998 & - & 33 & 43 & Spring \\
\hline Ionian Sea & D’Onghia et al., 1994 & - & 35 & 39 & - \\
\hline Eastern Ionian Sea & Kapiris and Thessalou-Legaki, 2009 & June-August & - & 39 & - \\
\hline Antalya Bay & This study & June-August & & 39 & April-July \\
\hline
\end{tabular}


and they were also lower than FMS (Deval et al., 2016). Since codend selectivity could not be the solution, my recommendation is to combine three types of control measures (effort controls, catch quotas and area closures) proposed by Stefansson \& Rosenberg (2005) for the deep-water fisheries management.

\section{Acknowledgements}

The author deeply thanks the captain and the crew of the R/V "Akdeniz Su", and the Ph.D. students, Olgaç Güven, Turhan Kebapçioğlu, Yasemin Kaya, İsmet Saygu and Gökçe Özgen for their help during the work at sea. Additional thanks to Y. Kaya, G. Özgen and I. Saygu for his valuable work in the laboratory. This study was financed partially by the Akdeniz University Research Fund, Projects No: 2010.01.0111.001 and 2011.02.0121.022.

\section{References}

Anonymous (2016). The Commercial Fish Catching Regulations in Seas and Inland Waters in 2016-2020 Fishing Period: Notification No. 2016/35. Minister of Agriculture and Rural Affair, General Directorate of Conservation and Inspection, Ankara: Republic of Turkey, $68 \mathrm{pp}$ (in Turkish).

Anonymous (2018). Fishery Statistics. State Institute of Statistics Prime Ministry Republic of Turkey.

http://www.tuik.gov.tr/PreTablo.do?alt_id=1005 (Acessed 20 September 2018).

AAVV (2008). Status of deep-sea Red Shrimps in Central and Eastern Mediterranean Sea. Final Report. Project Ref FISH/2004/03-32.

Bayhan, K.Y., Cartes, J.E., \& Fanelli, E. (2014). Biological condition and trophic ecology of the deep-water shrimp Aristaeomorpha foliacea in the Levantine Sea (SW Turkey). Mediterranean Marine Science, 16 (1), 103-116. https://dx.doi.org/10.12681/mms.867

Belcari, P., Viva, C., Mori, M., \& De Ranieri, S. (2003). Fishery and Biology of Aristaeomorpha foliacea (Risso, 1827) (Crustacea: Decapoda) in the Northern Tyrrhenian Sea (Western Mediterranean). Journal of Northwestern Atlantic Fishery Science, 31, 195-204.

Beverton, R.J.H., \& Holt, S.J. (1956). A review of methods for estimating mortality rates in exploited fish populations, with special reference to sources of bias in catch sampling. Rapp.P.-V.Réun. CIEM, 140, 67-83.

Branch, T.A., Kirkwood, G.P., Nicholson, S.A., Lawlor, B., \& Zara, S.J. (2000). Yield Version 1.0, MRAG Ltd, London, U.K.

Can, M.F., \& Aktaş, M. (2005). A preliminary study on population structure and abundance of Aristaeomorpha foliacea (Risso, 1827) (Decapoda, Natantia) in the deep water of the northeastern Mediterranean. Crustaceana, 78 (8), 941-946.

https://dx.doi.org/10.1163/156854005775197334

Carlucci, R., D’Onghia, G., Sion, L., Maiorano, P., \& Tursi, A. (2006). Selectivity parameters and size at first maturity in deep-water shrimps, Aristaeomorpha foliacea (Risso, 1827) and Aristeus antennatus (Risso, 1816), from the North-Western Ionian Sea (Mediterranean Sea). Hydrobiologia, 557 (1), 145-154. https://dx.doi.org/10.1007/s10750-005-1317-8

Cau, A., Carbonell, A., Follesa, M.C., Mannini, A., Relini, L.O., Politou, C.Y.. (2002). MEDITS-based information on the deep-water red shrimps Aristaeomorpha foliacea and Aristeus antennatus (Crustacea: Decapoda: Aristeidae). Scientia Marina, 66 (2), 103-124.

https://dx.doi.org/10.3989/scimar.2002.66s2103

Coll, M., Piroddi, C., Steenbeek, J., Kaschner, K., Ben Rais Lasram, F., Aguzzi, J. (2010). The Biodiversity of the Mediterranean Sea: Estimates, Patterns, and Threats. PLOS ONE, 5 (8), e11842.

https://dx.doi.org/10.1371/journal.pone.0011842

Demirci, A. (2006). A study on the deep sea trawl fishery in the Northeast Mediterranean, PhD Thesis, Department of Fishing and Processing Technology, Ege Üniversitesi Fen Bilimleri Enstitüsü, $134 \mathrm{pp}$ (in Turkish).

De Santis, S., Labate, A., Tursi, G., D’Onghia, G., \& Maiorano, P. (1999). Testicular activity in the shrimp Aristeus antennatus (Risso, 1816). pp: 903-914. F. R. Schram and J. C. von Vaupel Klein (Eds.). Crustaceans and the Biodiversity Crisis. Vol. I.

Deval, M.C., \& Froglia, C. (2016). New records of deep-sea decapod crustaceans in the Turkish Mediterranean Sea (North Levant Sea). Zoology in the Middle East, 62 (4), 323-330.

https://dx.doi.org/10.1080/09397140.2016.1250709

Deval, M.C., \& Kapiris, K. (2016). A review of biological patterns of the blue-red shrimp Aristeus antennatus in the Mediterranean Sea: case study of the population of Antalya Bay, eastern Mediterranean Sea. Scienta Marina, 80 (3), 339-348. https://dx.doi.org/10.3989/scimar.04411.22A

Deval, M.C., Kaya, Y., \& Olguner, T. (2019). Population dynamics and biological patterns of commercial crustacean species in the Antalya Bay, eastern Mediterranean Sea: II. The pink shrimp Parapenaeus longirostris Lucas, 1846 (article in progress).

Deval, M.C., Özgen, G., \& Özbilgin, H. (2016). Selectivity of 50 $\mathrm{mm}$ T0 and T90 codends for commercial shrimp species in the Turkish deep-water trawl fishery, Eastern Mediterranean. Journal of Applied Ichthyology, 32 (6), 1041-1057. https://dx.doi.org/10.1111/jai.13128

Deval, M.C., Yılmaz, S., \& Kapiris, K. (2017). Spatio temporal variations in decapod crustacean assemblages of bathyal ground in the Antalya Bay (Eastern Mediterranean). Turkish Journal of Fisheries and Aquatic Sciences, 17 (5), 967-979.

https://dx.doi.org/10.4194/1303-2712-v17_5_12

Deval, M.C., Bök, T., Ateş, C., \& Tosunoğlu, Z. (2009). Comparison of the size selectivity of diamond (PA) and square (PE) mesh codends for deepwater crustacean species in the Antalya Bay, eastern Mediterranean. Journal of Applied Ichthyology, 25 (4), 372-380. http://dx.doi.org/10.1111/j.1439-0426.2009.01239.x

Deval, M.C., Kebapçioğlu, T., Güven O., \& Olguner, M.T. (2018). Population pattern and dynamics of the Bluemouth Helicolenus dactylopterus (Delaroche, 1809) in the eastern Mediterranean Sea. Journal of Applied Ichthyology, 34 (3), 568-580. https://dx.doi.org/10.1111/jai.13613

Diekert, F.K. (2015). Growth Overfishing: The Race to Fish Extends to the Dimension of Size. Environmental and Resource Economics, 52 (4), 549-572. https://dx.doi.org/10.1007/s10640-012-9542-x 
D’Onghia, G., Matarrese, A., Tursi, A., \& Maiorano, P. (1994). Biology of Aristeus antennatus and Aristaeomorpha foliacea in the Ionian Sea (Central Mediterranean Sea). In M.L. Bianchini, \& S. Ragonese (Eds.), Life cycles and fisheries of the deep-water red shrimps Aristaeomorpha foliacea and Aristeus antennatus (Proceedings of the International Workshop), Mazara del Vallo, Italy, 28-30 April 1994, N.T.R.-I.T.P.P. Spec. Publ., 3: pp.55-56.

D’Onghia, G., Maiorano, P., Matarrese, A., \& Tursi, A. (1998). Distribution, biology, and population dynamics of Aristaeomorpha foliacea (Risso, 1827) (Decapoda, Natantia, Aristeidae) in the north-western Ionian Sea (Mediterranean Sea). Crustaceana, 71 (5), 518-544. https://dx.doi.org/10.1163/156854098X00419

Gayalino, F.C., Sparre, O., \& Pauly, D. (2002). The FAO-ICLARM Stock Assessment Tools (FiSAT II) Program Package. FAO, Rome.

ICES, 2010. Report of the Workshop on crustaceans (Aristeus antennatus, Aristaeo-morpha foliacea, Parapenaeus longirostris, Nephrops norvegicus) maturity stages (WKMSC), 19-23 October 2009, Messina, Italy. ICES CM 2009/ACOM, No 46, 77pp.

Kapiris, K., \& Thessalou-Legaki, M. (2009). Comparative reproduction aspects of the deep-water shrimps Aristaeomorpha foliacea and Aristeus antennatus (Decapoda, Aristeidae) in the Greek Ionian Sea (Eastern Mediterranean). International Journal of Zoology, ID 979512, 9 pp. http://dx.doi.org/10.1155/2009/979512

Kirkwood, G.P., Aukland, R., \& Zara, S.J. (2001). Length Frequency Distribution Analysis (LFDA), Version 5.0. MRAG Ltd, London, UK.

Mura, M., Campisi, S., \& Cau, A. (1992). Osservazioni sulla biologia riproduttiva negli Aristeidi demersali del Mediterraneo centro occidentale. Oebalia, 17, 75-80.

Palmas, F., Addis, P., Cabiddu, S., Cuccu, D., Follesa, M., et al. (2014). Distribution of spawning and nursery grounds for deep-water red shrimps in the central western Mediterranean Sea. Mediterranean Marine Science, 16 (1), 117-127. http://dx.doi.org/10.12681/mms.859

Papaconstantinou, C., \& Kapiris, K. (2003). The biology of the giant red shrimp (Aristaeomorpha foliacea) at an unexploited fishing ground in the Greek Ionian Sea. Fisheries Research, 62 (1), 37-51. https://dx.doi.org/10.1016/S0165-7836(02)00254-0

Pauly, D. (1980). On the interrelationship between natural mortality, growth parameters, and mean environmental temperature in 175 fish stocks. ICES Journal of Marine Science, 39 (2), 175-192. http://dx.doi.org/10.1093/icesjms/39.2.175

Pauly, D. (1984). Length-converted catch curves: a powerful tool for fisheries research in the tropics (Part II). ICLARM Fishbyte, 2 (1): 17-19.

Politou, C.Y., Kapiris, K., Maiorano, P., Capezzuto, F., \& Dokos, J. (2004). Deep-sea Mediterranean biology: the case of
Aristaeomorpha foliacea (Risso, 1827) (Crustacea: Decapoda: Aristeidae). Scientia Marina, 68 (3), 117-127. https://dx.doi.org/10.3989/scimar.2004.68s3129

Powell, D.G. (1979). Estimation of mortality and growth parameters from the length-frequency in the catch. Rapp. P.-V. Réun. 175, 167-169.

Ragonese, S., \& Bianchini, M.L. (1995). Size at sexual maturity in red shrimp females, Aristaeomorpha foliacea, from the Sicilian channel (Mediterranean Sea). Crustaceana, 68 (1), 73-82. https://dx.doi.org/10.1163/156854095X00395

Ragonese, S., Bianchini, M. L., \& Gallucci, V.F. (1994). Growth and mortality of the red shrimp Aristaeomorpha foliacea, from the Sicilian Channel (Mediterranean Sea). Crustaceana, 67 (3), 348-361. https://dx.doi.org/10.1163/156854094X00459

Ragonese, S., Bianchini, M.L., \& Di Stefano, L. (2002). Trawl cod-end selectivity for the deep-water red shrimp (Aristaeomorpha foliacea, Risso, (1827) in the Strait of Sicily (Mediterranean Sea). Fisheries Research, 57 (2), 131-144. https://dx.doi.org/10.1016/S0165-7836(01)00342-3

Ragonese, S., Andreoli, M.G., Bono, G., Giusto, G.B., Rizzo, P., et al., (2004). Overview of the available biological information on demersal resources of the Strait of Sicily. GCP/RER/010/ITA/MSM-TD-02. MedSudMed Technical Documents, 2, 67-74.

Righini, P., \& Abella, A. (1994). Life cycle of Aristeus antennatus and Aristaeomorpha foliacea in the Northern Tyrrhenian Sea. In: Life Cycles and Fisheries of the Deep-Water Red Shrimps Aristaeomorpha foliacea and Aristeus antennatus. Bianchini, M.L., Ragonese, S. (Eds.) N.T.R.I.T.P.P. Spec. Publ., 3, 29-30.

Rinelli, P., Bianchini, M.L., Casciaro, L., Giove, A., Mannini, A., et al., (2013). Occurrence and abundance of the deepwater red shrimps Aristeus antennatus (Risso, 1816) and Aristaeomorpha foliacea (Risso, 1827) in the central eastern Mediterranean Sea. Cahiers de Biologie Marine, 54 (3), 335-347. https://dx.doi.org/10.21411/CBM.A.11EB0E18

Sardà, F., \& Demestre, M. (1989). Shortening of the rostrum and rostral variability in Aristeus antennatus (Risso, 1816) (Decapoda: Aristeidae). Journal of Crustacean Biology, 9 (4), 570-577. https://dx.doi.org/10.1163/193724089X00584

Stefansson, G., \& Rosenberg, A.A. (2005). Combining control measures for more effective management of fisheries under uncertainty: quotas, effort limitation and protected areas. Philosophical transactions of the Royal Society of London. Series B, Biological sciences, 360 (1453), 133-46.

Yahiaoui, M. (1994). Distribution and reproduction cycle of Aristeus antennatus and Aristaeomorpha foliacea in Algeria. In: Life Cycles and Fisheries of the Deep-Water Red Shrimps Aristaeomorpha foliacea and Aristeus antennatus. Bianchini, M.L., Ragonese, S. (Eds.) N.T.R.I.T.P.P. Spec. Publ., 3, pp. 51-52. 